University of Wollongong

Research Online

Australian Institute for Innovative Materials -

Papers

Australian Institute for Innovative Materials

$1-1-2013$

Spinel LiNixMn2-xO4 as cathode material for aqueous rechargeable lithium batteries

F X. Wang

Fudan University

S Y. Xiao

Fudan University

Y Shi

University of Wollongong, ys099@uowmail.edu.au

L L. Liu

Fudan University

Y S. Zhu

Fudan University

See next page for additional authors

Follow this and additional works at: https://ro.uow.edu.au/aiimpapers

Part of the Engineering Commons, and the Physical Sciences and Mathematics Commons

Research Online is the open access institutional repository for the University of Wollongong. For further information contact the UOW Library: research-pubs@uow.edu.au 


\title{
Spinel LiNixMn2-xO4 as cathode material for aqueous rechargeable lithium batteries
}

\begin{abstract}
Ni-doped spinel LiNixMn2-xO4 $(x=0,0.05,0.10)$ samples were prepared by a sol-gel method. Structure and morphology of the samples were characterized by X-ray diffraction, scanning electron microscopy, Brunnauer-Emmet-Teller method and inductively coupled plasma atomic absorption spectrometry. The electrochemical behavior as a cathode material (positive mass) for aqueous rechargeable lithium batteries (ARLBs) was investigated by cyclic voltammetry, electrochemical impedance spectroscopy, capacity measurements and cycling tests. The results show that the LiNi $0.1 \mathrm{Mn} 1.904$ electrode presents the best rate and cycling performance but low reversible capacity. In contrast, the LiNi 0.05Mn1.9504 electrode shows a higher reversible capacity and relatively good cycling behavior. At a current density of $150 \mathrm{~mA} \mathrm{~g}-1$, LiNi0.05Mn1.9504 delivers a reversible capacity of $102 \mathrm{~mA} \mathrm{~h} \mathrm{g-1.} \mathrm{At} \mathrm{the} \mathrm{relative} \mathrm{high} \mathrm{current}$ densities of 1500 and $3000 \mathrm{~mA} \mathrm{g-1}$, the LiNi 0.05Mn1.9504 electrode still delivers reversible capacities of 95.0 and $88.7 \mathrm{~mA} \mathrm{~h} \mathrm{g-1}$, respectively. The Ni-doped samples show excellent cycling life in $0.5 \mathrm{~mol} \mathrm{L-1} \mathrm{Li}$ 2SO4 aqueous solution. The capacity retention ratios for LiNi0.05Mn1.9504 and LiNi0.10Mn 1.9004 after 800 cycles at a current density of $1500 \mathrm{~mA} \mathrm{~g}-1$ are $79.4 \%$ and $91.1 \%$, respectively, much higher than that for the undoped LiMn2O4 at only 37.8\%. 2013 Elsevier Ltd. 2013 Elsevier Ltd. All rights reserved.
\end{abstract}

\section{Keywords}

xo4, linixmn2, lithium, rechargeable, batteries, aqueous, spinel, material, cathode

\author{
Disciplines \\ Engineering | Physical Sciences and Mathematics
}

\section{Publication Details}

Wang, F. X., Xiao, S. Y., Shi, Y., Liu, L. L., Zhu, Y. S., Wu, Y. P., Wang, J. Z. \& Holze, R. (2013). Spinel

LiNixMn2-xO4 as cathode material for aqueous rechargeable lithium batteries. Electrochimica Acta, 93 (March), 301-306.

\section{Authors}

F X. Wang, S Y. Xiao, Y Shi, L L. Liu, Y S. Zhu, Y P. Wu, J. Z. Wang, and R Holze 
Spinel $\mathrm{LiNi}_{x} \mathrm{Mn}_{2-x} \mathrm{O}_{4}$ as cathode material for aqueous rechargeable lithium batteries

F.X. Wang ${ }^{\text {a }}$, S.Y. Xiao ${ }^{\text {a }}$, Y. Shi ${ }^{\text {abb }}$, L.L. Liu ${ }^{a}$, Y.S. Zhu ${ }^{a}$, Y.P. Wu ${ }^{1, a},{ }^{*}$, J.Z. Wang ${ }^{\text {b, }}{ }^{*}$ R. Holze ${ }^{1, c, *}$ ${ }^{a}$ New Energy and Materials Laboratory (NEML), Department of Chemistry \& Shanghai Key Laboratory of Molecular Catalysis and Innovative Materials, Fudan University Shanghai 200433, China

${ }^{\mathrm{b}}$ Institute for Superconducting and Electronic Materials, University of Wollongong, Australia ${ }^{\circ}$ Technische Universität Chemnitz, Institut für Chemie, AG Elektrochemie, D-09107 Chemnitz, Germany

\begin{abstract}
Ni-doped spinel $\mathrm{LiNi}_{x} \mathrm{Mn}_{2-x} \mathrm{O}_{4}(x=0,0.05,0.10)$ samples were prepared by a sol-gel method. Structure and morphology of the samples were characterized by X-ray diffraction, scanning electron microscopy, Brunnauer-Emmet-Teller method and inductively coupled plasma atomic absorption spectrometry. The electrochemical behavior as a cathode material (positive mass) for aqueous rechargeable lithium batteries (ARLBs) was investigated by cyclic voltammetry, electrochemical impedance spectroscopy, capacity measurements and cycling tests. The results show that the $\mathrm{LiNi}_{0.1} \mathrm{Mn}_{1.9} \mathrm{O}_{4}$ electrode presents the best rate and cycling performance but low reversible capacity. In contrast, the $\mathrm{LiNi}_{0.05} \mathrm{Mn}_{1.95} \mathrm{O}_{4}$ electrode shows a higher reversible capacity and relatively good cycling behavior. At a current density of $150 \mathrm{~mA} \mathrm{~g}{ }^{-1}, \mathrm{LiNi}_{0.05} \mathrm{Mn}_{1.95} \mathrm{O}_{4}$ delivers a reversible capacity of $102 \mathrm{mAh} \mathrm{g}^{-1}$. At the relative high current densities of 1500 and

\footnotetext{
${ }^{1}$ ISE Member

* Correspondence, wuyp@fudan.edu.cn (Wu),jiazhao@uow.edu.au (Wang), rudolf.holze@chemie.tu-chemnitz.de (Holze).
} 
$3000 \mathrm{~mA} \mathrm{~g}^{-1}$, the $\mathrm{LiNi}_{0.05} \mathrm{Mn}_{1.95} \mathrm{O}_{4}$ electrode still delivers reversible capacities of 95.0 and 88.7 $\mathrm{mAh} \mathrm{g}^{-1}$, respectively. The Ni-doped samples show excellent cycling life in $0.5 \mathrm{~mol} \mathrm{~L}^{-1} \mathrm{Li}_{2} \mathrm{SO}_{4}$ aqueous solution. The capacity retention ratios for $\mathrm{LiNi}_{0.05} \mathrm{Mn}_{1.95} \mathrm{O}_{4}$ and $\mathrm{LiNi}_{0.10} \mathrm{Mn}_{1.90} \mathrm{O}_{4}$ after 800 cycles at a current density of $1500 \mathrm{~mA} \mathrm{~g}^{-1}$ are $79.4 \%$ and $91.1 \%$, respectively, much higher than that for the undoped $\mathrm{LiMn}_{2} \mathrm{O}_{4}$ at only $37.8 \%$.

Keywords: Aqueous rechargeable lithium battery; cathode; $\mathrm{LiMn}_{2} \mathrm{O}_{4}$; Ni doping; electrochemical performance 


\section{Introduction}

Lithium ion batteries (LIBs) have become one of the most important energy storage technologies today in particular for mobile and portable applications. They were invented in the early 1990s, and now are widely used as power sources for electronic devices such as laptops, cellular phones, electric power tools etc. [1 - 3]. Spinel-type $\mathrm{LiMn}_{2} \mathrm{O}_{4}$ and its derivatives have been used as cathode material for the lithium ion batteries because of their low cost, abundance in natural sources, and easy preparation [2]. The electrochemistry of $\mathrm{LiMn}_{2} \mathrm{O}_{4}$ in organic electrolytes has been extensively studied over the past two decades [4 - 10]. Although lithium ion batteries are considered to be the most successful electrochemical devices with high energy density, they are still associated with the risk of safety accidents because of the flammability of the organic electrolytes and improper use such as overcharging or short-circuiting. Moreover, the spinel $\mathrm{LiMn}_{2} \mathrm{O}_{4}$ in the organic electrolyte solutions does not present as excellent cycling life as $\mathrm{LiFePO}_{4}$ due the instability of the spinel structure and the dissolution of manganese into the electrolyte solution during cycling $[11,12]$. As a result, the urgent environmental and economic problems unceasingly promote the further development of safer, less expensive and greener battery materials and devices.

To solve these problems, an attractive approach is to use an aqueous electrolyte solution for lithium batteries, in which $\mathrm{Li}^{+}$-ions are reversibly intercalated into and deintercalated from the active masses with a subsequent charge transfer similar to that in the organic lithium ion battery. In the middle of the 1990s, a rechargeable lithium battery with an aqueous electrolyte was developed [13, 14]. Obviously, the cost of aqueous rechargeable lithium batteries (ARLBs) will be low since electrode and electrolyte materials are not expensive and its assembling process is easy. In addition, it is inherently safe by avoiding the use of flammable organic electrolytes. Moreover, the ionic conductivity of aqueous electrolytes is high, about two orders of magnitude 
higher than that of organic electrolytes [15], which ensures high rate capability and thus high specific power. Therefore, ARLBs have received wide interest especially in recent years [15 26]. However, the traditional micrometer-sized materials do not show good electrochemical performance in an aqueous electrolyte [18]. Recently, nanostructured $\mathrm{LiMn}_{2} \mathrm{O}_{4}$ samples were prepared and their electrochemical properties, especially reversible capacity, rate capability and cycling life as cathode materials for the ARLBs, have been markedly improved [24 - 28]. For example, a porous $\mathrm{LiMn}_{2} \mathrm{O}_{4}$ consisting of nanograins shows still $93 \%$ capacity retention even after 10000 full cycles [24]. It is known that the uniformity of nanostructured $\mathrm{LiMn}_{2} \mathrm{O}_{4}$ is not easy to control. The use of traditional micrometer-sized materials will be of great promise for the practical application of ARLBs. In order to achieve this goal, doping micrometer-sized $\mathrm{LiMn}_{2} \mathrm{O}_{4}$ with several cations (such as $\mathrm{Co}, \mathrm{Al}, \mathrm{Cr}$ and $\mathrm{Mg}$ ) would be a good way, which has been proved to reduce Jahn-Teller distortion effectively in organic electrolyte [5, 10, 29, 30]. However, few studies about cation-doped $\mathrm{LiMn}_{2} \mathrm{O}_{4}$ (only $\mathrm{Cr}, \mathrm{Al}, \mathrm{Fe}[16,18,20]$ ) in aqueous electrolyte have been reported up to now. Herein we report for the first time the electrochemical behavior of spinel-type $\mathrm{LiNi}_{x} \mathrm{Mn}_{2-x} \mathrm{O}_{4}(\mathrm{x}=0,0.05,0.1)$ as cathode materials for aqueous rechargeable lithium batteries. We found, that Ni-doping of $\mathrm{LiMn}_{2} \mathrm{O}_{4}$ can greatly improve its rate behavior and capacity retention at large current densities in aqueous electrolyte. 


\section{Experimental}

The synthesis of spinel $\mathrm{LiNi}_{x} \mathrm{Mn}_{2-x} \mathrm{O}_{4}(x=0,0.05,0.10)$ particles was carried out according to a previously reported method [29, 30] with minor modifications. Briefly, stoichiometric amounts of lithium acetate $\left[\mathrm{Li}\left(\mathrm{CH}_{3} \mathrm{COO}\right) \cdot 2 \mathrm{H}_{2} \mathrm{O}\right](0.01 \mathrm{~mol})$, manganese acetate $\left[\mathrm{Mn}\left(\mathrm{CH}_{3} \mathrm{COO}\right)_{2} \cdot 4 \mathrm{H}_{2} \mathrm{O}\right]$, and nickel acetate $\left[\mathrm{Ni}\left(\mathrm{CH}_{3} \mathrm{COO}\right)_{2} \cdot 4 \mathrm{H}_{2} \mathrm{O}\right]$ with the atomic ratio $\mathrm{Li}: \mathrm{Ni}: \mathrm{Mn}=1.05: \mathrm{x}:(2-x)$, where $x$ is $0,0.05$ and 0.10 , respectively, were dissolved in distilled water and mixed with an aqueous solution of citric acid. The citric acid was used as a chelating agent and a fuel for combustion (the molar ratio of carboxylic acid groups in citric acid to metal ions was fixed at 1:1). Then ammonia was added slowly to this solution with constant stirring until a $\mathrm{pH}$ of about 7 was achieved. The resultant solutions were evaporated at $80{ }^{\circ} \mathrm{C}$ until transparent sols were obtained. To remove water, the obtained precursors were dried under vacuum at $120{ }^{\circ} \mathrm{C}$ overnight. The resulting gel precursors were burned at $450{ }^{\circ} \mathrm{C}$ for $6 \mathrm{~h}$, then $800{ }^{\circ} \mathrm{C}$ for $10 \mathrm{~h}$ in air. The rate of temperature increase was $3{ }^{\circ} \mathrm{C} \mathrm{min}{ }^{-1}$. All chemicals were of analytical grade, and the solutions were prepared with distilled water.

The electrodes were prepared by mixing powdered samples, acetylene black and polytetrafluoroethylene (PTFE) in a weight ratio of 8:1:1 with the help of ethanol. The mixture was pressed into a film, and then dried at $120{ }^{\circ} \mathrm{C}$ overnight to act as working electrodes. After drying, the film was cut into disks of about $2 \mathrm{mg}\left(0.36 \mathrm{~cm}^{2}\right.$ in area and $0.4 \mathrm{~mm}$ in thickness $)$. These disks were pressed onto a Ni-grid at a pressure of $20 \mathrm{MPa}$ to act as the working electrodes. Cyclic voltammetry (CV), electrochemical impedance measurements, and the first chargedischarge profiles of the $\mathrm{LiNi}_{\mathrm{x}} \mathrm{Mn}_{2-\mathrm{x}} \mathrm{O}_{4}(\mathrm{x}=0,0.05$ and 0.10$)$ electrodes were performed in 0.5 mol L-1 $\mathrm{Li}_{2} \mathrm{SO}_{4}$ solution (small amounts of $\mathrm{LiOH}$ were added to ensure its $\mathrm{pH}$ value is 7) with a three-electrode cell, in which a Ni-grid and a saturated calomel electrode (SCE) were used as counter and reference electrodes, respectively. The CV data were collected between 0 and $1.2 \mathrm{~V}$ 
(vs. SCE) at different scan rates. The $\mathrm{LiNi}_{\mathrm{x}} \mathrm{Mn}_{2-\mathrm{x}} \mathrm{O}_{4}$ electrodes were charged and discharged in the potential range of $0.3-1.05 \mathrm{~V}$ (vs. SCE) at various current densities. The electrochemical impedance spectra (EIS) were recorded from $10^{5}$ to $0.1 \mathrm{~Hz}$.

Activated carbon (AC) with a specific surface area of about $2800 \mathrm{~m}^{2} \mathrm{~g}^{-1}$ measured by a Brunauer-Emmet-Teller (BET) method was purchased from Ningde Xinseng Chemical Industrial Co., Ltd. and used as received without further treatment. The activated carbon electrodes were prepared in the same way as the $\mathrm{LiNi}_{x} \mathrm{Mn}_{2-x} \mathrm{O}_{4}(x=0,0.05,0.10)$ electrodes [18]. Since it can absorb and desorb $\mathrm{Li}^{+}$ions very quickly, it will not have any adverse effects on the properties of the working electrodes [24]. A two-electrode cell consisting of the above $\operatorname{LiNi}_{x} \mathrm{Mn}_{2-x} \mathrm{O}_{4}(x=0$, 0.05, 0.10) working electrode and the activated carbon counter electrode with a distance of about $1 \mathrm{~cm}$ was used to test the cycling behavior of the as-prepared samples in $0.5 \mathrm{~mol} \mathrm{~L}^{-1}$ $\mathrm{Li}_{2} \mathrm{SO}_{4}$ solution on a cell tester (Land 2001A). The mass ratio of the spinel $\mathrm{LiNi}_{x} \mathrm{Mn}_{2-x} \mathrm{O}_{4}(x=0$, $0.05,0.10)$ to the activated carbon was fixed at about 1:3.5. All tests were carried out at room temperature.

The X-ray diffraction (XRD) patterns were collected using a Rigaku D/MAX-IIA X-ray diffractometer with $\mathrm{Cu} \mathrm{K} \alpha$ radiation. Data were collected in a step-scan mode in the range of 10 - $90^{\circ}$ with intervals of $8^{\circ} \mathrm{min}^{-1}$. Scanning electron micrographs (SEM) were obtained on a Philips microscope XL30 operated at $25 \mathrm{kV}$. The specific area was measured according to the BET method using a Micromeritics Tristar ASAP 3000 BET apparatus with liquid nitrogen at 77 K. Elemental analysis was obtained on a Thermo E. IRIS Duo inductively coupled plasma atomic absorption spectrometer (ICP-AAS). 


\section{Results and discussion}

The XRD patterns of the as-prepared samples $\mathrm{LiNi}_{x} \mathrm{Mn}_{2-x} \mathrm{O}_{4}(x=0,0.05,0.10)$ are shown in Fig. 1. The diffraction peaks can be indexed to the spinel with a space group $F d 3 m$, they are in good agreement with the standard pattern (JCPDS, Card No.35-0782) [31]. Fig. 2 shows the SEM micrographs of the samples. Their particle sizes are in the sub-micrometer range from 200 to $400 \mathrm{~nm}$. There is not much difference in the morphology since the preparation method is the same for all samples and compositions. Table 1 lists the chemical compositions and surface areas of the samples. For the as-prepared samples, the experimental $\mathrm{Ni} / \mathrm{Mn}$ ratios agree basically with the target stoichiometry. The BET specific surface area of the samples are 2.30, 2.09 and $1.97 \mathrm{~m}^{2} \mathrm{~g}^{-1}$, respectively, for $\mathrm{LiMn}_{2} \mathrm{O}_{4}, \mathrm{LiNi}_{0.05} \mathrm{Mn}_{1.95} \mathrm{O}_{4}$ and $\mathrm{LiNi}_{0.10} \mathrm{Mn}_{1.9} \mathrm{O}_{4}$. The reason for these differences needs further study.

The CVs of the samples at different scan rates are presented in Fig. 3(a-c). There are two redox couples at low scan rates. The anodic and cathodic peaks correspond to lithium de-intercalation and intercalation. The splitting of the redox peaks into two couples shows, that the electrochemical reaction of the de-intercalation and intercalation of $\mathrm{Li}^{+}$ions consists of two processes, which is consistent with the results in both organic and aqueous electrolytes [2, 5, 6, 12, 19, 24, 33, 34]. At the low scan rate, two separate couples of redox peaks can be observed for all electrodes. At the lowest scan rate $(1 \mathrm{mV} / \mathrm{s})$, the anodic current peak of the doped sample ( $\left.\mathrm{LiNi}_{0.10} \mathrm{Mn}_{0.90} \mathrm{O}_{4}\right)$ is less well-defined in comparison to those of the undoped phase $\left(\mathrm{LiMn}_{2} \mathrm{O}_{4}\right)$, which indicates that the substitution of nickel ions may eliminate the small Li-Li repulsion energy difference between the half-filled 8a sites in $\mathrm{Li}_{0.5} \mathrm{Mn}_{2} \mathrm{O}_{4}$ and the completely filled sites in $\mathrm{LiMn}_{2} \mathrm{O}_{4}[11,29]$.

With increasing scan rate, the separation between the two redox pairs becomes smaller. It is noted that the peaks of Ni-doped samples retain the well-defined shape when the scan rate 
increases to $8 \mathrm{mV} \mathrm{s}^{-1}$ (Fig. 3b and c), which indicates that the $\mathrm{Ni}$ doped electrodes can be charged and discharged at larger current densities. In contrast, the peaks of the undoped $\mathrm{LiMn}_{2} \mathrm{O}_{4}$ become less distinguishable at this scan rate (Fig. 3a). When the scan rate continues to increase to $10 \mathrm{mV} \mathrm{s}^{-1}$, the $\mathrm{LiNi}_{0.1} \mathrm{Mn}_{1.9} \mathrm{O}_{4}$ electrode still retains the well-defined shape, which implies that it will present the best rate behavior.

The Nyquist plots (Fig. 3d) of the $\mathrm{LiNi}_{\mathrm{x}} \mathrm{Mn}_{2-\mathrm{x}} \mathrm{O}_{4}(\mathrm{x}=0,0.05$ and 0.1$)$ electrodes show a semicircle at mid-high frequency and a linear region at low frequencies. The linear region corresponds to the diffusion process of $\mathrm{Li}^{+}$-ions in the electrode. The semicircles correspond to a parallel combination of charge-transfer resistance $\left(R_{\mathrm{ct}}\right)$ and double-layer capacitance $[24,35]$. The $R_{\mathrm{ct}}$ values can be estimated from the diameter of the semicircle on the real axis. It can be seen that the Ni-doped samples exhibit a smaller $R_{\mathrm{ct}}$ than the undoped one, suggesting that the doping of a certain amount of Ni ions could effectively decrease the charge transfer resistance in the spinel. The first charge-discharge profiles of the $\mathrm{LiNi}_{x} \mathrm{Mn}_{2-\mathrm{x}} \mathrm{O}_{4}(\mathrm{x}=0,0.05$ and 0.10$)$ electrodes in the aqueous electrolyte at different current densities are shown in Fig. 4. There are two distinct charge and discharge plateaus, which reflect a two-stage $\mathrm{Li}^{+}$-ion de-intercalation and intercalation behavior and consistent with both the obtained CV curves and other reports [5, 6]. For the $\mathrm{LiNi}_{0.1} \mathrm{Mn}_{1.9} \mathrm{O}_{4}$ electrode the plateaus became less distinct, suggesting that the local distortion of the host structure resulting from the substitution of nickel ions may eliminate the small $\mathrm{Li}$-Li repulsion energy difference between the half-filled 8a sites in $\mathrm{Li}_{0.5} \mathrm{Mn}_{2} \mathrm{O}_{4}$ and the completely filled sites in $\mathrm{LiMn}_{2} \mathrm{O}_{4}[11,29,36]$.

At a charge/discharge current density of $150 \mathrm{~mA} \mathrm{~g}^{-1}$ (Fig. 4a) the $\mathrm{LiMn}_{2} \mathrm{O}_{4}$ electrode exhibits initial discharge capacities of $103 \mathrm{mAh} \mathrm{g}^{-1}$, higher than $\mathrm{LiNi}_{0.05} \mathrm{Mn}_{1.95} \mathrm{O}_{4}$ electrode (102 $\mathrm{mAh} \mathrm{g}^{-1}$ ) and $\mathrm{LiNi}_{0.1} \mathrm{Mn}_{1.9} \mathrm{O}_{4}$ electrode (83.0 $\mathrm{mAh} \mathrm{g}^{-1}$ ). Substitution was found to decrease the capacity by reducing the quantity of oxidisable $\mathrm{Mn}^{3+}$. This is similar to the doping effects of $\mathrm{LiNi}_{\mathrm{x}} \mathrm{Mn}_{2-\mathrm{x}} \mathrm{O}_{4}$ 
in the organic electrolytes $[5,10]$. The initial capacities of the electrodes decrease with the increasing current density. At the current density of $300 \mathrm{~mA} \mathrm{~g}{ }^{-1}$ (Fig. 4b), the $\mathrm{LiMn}_{2} \mathrm{O}_{4}$, $\mathrm{LiNi}_{0.05} \mathrm{Mn}_{1.95} \mathrm{O}_{4}$ and $\mathrm{LiNi}_{0.10} \mathrm{Mn}_{1.90} \mathrm{O}_{4}$ electrodes deliver discharge capacities of 97.2, 101 and $74.1 \mathrm{mAh} \mathrm{g}^{-1}$, respectively. Even at the relative high current density of 1500 and $3000 \mathrm{~mA} \mathrm{~g}^{-1}$ (Fig. 4c and d), the $\mathrm{LiNi}_{0.05} \mathrm{Mn}_{1.95} \mathrm{O}_{4}$ electrodes still deliver discharge capacities of 95.0 and 88.7 mAh g ${ }^{-1}$, respectively. The capacities for $\mathrm{LiNi}_{0.10} \mathrm{Mn}_{1.90} \mathrm{O}_{4}$ electrodes are 71.9 and $69.0 \mathrm{mAh} \mathrm{g}^{-1}$ at 1500 and $3000 \mathrm{~mA} \mathrm{~g}^{-1}$, respectively. However, the undoped spinel $\mathrm{LiMn}_{2} \mathrm{O}_{4}$ electrodes deliver only 83.9 and $67.2 \mathrm{mAh} \mathrm{g}^{-1}$ at the same current densities. For the $\mathrm{LiNi}_{0.05} \mathrm{Mn}_{1.95} \mathrm{O}_{4}$ electrode, these improved properties are further confirmed in the rate capabilities test at the current density ranging from 300 to $5000 \mathrm{~mA} \mathrm{~g}^{-1}$ (Fig. 5). Fig. 5 suggests that the $\mathrm{LiNi}_{0.1} \mathrm{Mn}_{1.9} \mathrm{O}_{4}$ electrode presents the best rate behavior, but its reversible capacity is lower. The $\mathrm{LiNi}_{0.05} \mathrm{Mn}_{1.95} \mathrm{O}_{4}$ electrode shows better rate capabilities and could deliver $99.8 \mathrm{mAh} \mathrm{g}^{-1}$ at the charge/discharge current density of $1000 \mathrm{~mA} \mathrm{~g}^{-1}$. In contrast, the undoped $\mathrm{LiMn}_{2} \mathrm{O}_{4}$ and $\mathrm{LiNi}_{0.1} \mathrm{Mn}_{1.9} \mathrm{O}_{4}$ exhibit discharge capacities of 83.8 and $73.8 \mathrm{mAh} \mathrm{g}^{-1}$, respectively. Moreover, after 50 cycles, as the charge and discharge current densities are reduced from 5000 to $300 \mathrm{mAh}$ $\mathrm{g}^{-1}$, the discharge capacity of the doped $\mathrm{LiNi}_{0.05} \mathrm{Mn}_{1.95} \mathrm{O}_{4}$ and $\mathrm{LiNi}_{0.1} \mathrm{Mn}_{1.9} \mathrm{O}_{4}$ electrodes recovered nearly without capacity loss, but the undoped spinel shows more than $9 \%$ capacity fading.

The cycling performance of $\mathrm{LiNi}_{x} \mathrm{Mn}_{2-x} \mathrm{O}_{4}(\mathrm{x}=0,0.05,0.10)$ electrodes measured by using activated carbon (AC) as the anode in a potential range of $0-1.8 \mathrm{~V}$ is shown in Fig. 6. After 300 cycles at the current density of $300 \mathrm{~mA} \mathrm{~g}^{-1}$, the capacity of the undoped cathode material decreases to $78.9 \mathrm{mAh} \mathrm{g}^{-1}$, about $76.6 \%$ capacity retention. In contrast, the $\mathrm{LiNi}_{0.05} \mathrm{Mn}_{1.95} \mathrm{O}_{4}$ electrode fades from 102 to $89.7 \mathrm{mAh} \mathrm{g}^{-1}$, about $87.9 \%$ capacity retention, which is superior to that reported with aqueous electrolyte $[15,16,18,23]$. For the $\mathrm{LiNi}_{0.1} \mathrm{Mn}_{1.9} \mathrm{O}_{4}$ electrode, though its 
reversible capacity is the smallest, it only fades from 76.9 to $73.1 \mathrm{mAh} \mathrm{g}^{-1}$, about $95.1 \%$ capacity retention after 300 cycles. After 800 cycles at a current density of $1500 \mathrm{mAg}^{-1}$, the discharge capacity of the undoped $\mathrm{LiMn}_{2} \mathrm{O}_{4}$ decreases rapidly to $31.6 \mathrm{mAh} \mathrm{g}^{-1}$. Similar to the cycling at the low current density, the doped $\mathrm{LiNi}_{\mathrm{x}} \mathrm{Mn}_{2-\mathrm{x}} \mathrm{O}_{4}$ electrodes also present better cycling performance. The $\mathrm{LiNi}_{0.05} \mathrm{Mn}_{1.95} \mathrm{O}_{4}$ and $\mathrm{LiNi}_{0.10} \mathrm{Mn}_{1.90} \mathrm{O}_{4}$ can still retain 74.9 (79.4 \%) and 71.9 $\mathrm{mAh} \mathrm{g}^{-1}$ (91.1 \%). It is clear that Ni-doping can effectively improve the cycling performance of the spinel $\mathrm{LiMn}_{2} \mathrm{O}_{4}$. One reason for this improvement is that the doped Ni-ions enhance the stability of the octahedral sites in the spinel structure due to the stronger Ni-O bond (bond energy: $1029 \mathrm{~kJ} \mathrm{~mol}^{-1}$ ) [37]. In the case of $\alpha-\mathrm{MnO}_{2}$, the bond energy of $\mathrm{Mn}-\mathrm{O}$ is $946 \mathrm{~kJ} \mathrm{~mol}^{-1}$. Moreover, substitution of manganese by $\mathrm{Ni}$ ions decreases the concentration of $\mathrm{Mn}^{3+}$ and reduces the Jahn-Teller distortion [29, 30]. The smaller capacity of the $\mathrm{LiNi}_{0.10} \mathrm{Mn}_{1.90} \mathrm{O}_{4}$ can also be partly attributed to the lattice contraction [37] beside less $\mathrm{Mn}^{3+}$ ions.

\section{Conclusions}

In summary, the Ni-doped spinel-type $\mathrm{LiNi}_{x} \mathrm{Mn}_{2-x} \mathrm{O}_{4}(\mathrm{x}=0,0.05,0.10)$ cathode materials were prepared by a sol-gel method. The $\mathrm{LiNi}_{0.05} \mathrm{Mn}_{1.95} \mathrm{O}_{4}$ electrode shows a higher reversible capacity and relatively good rate behavior. At a current density of $150 \mathrm{~mA} \mathrm{~g}{ }^{-1}$, the $\mathrm{LiNi}_{0.05} \mathrm{Mn}_{1.95} \mathrm{O}_{4}$ electrodes deliver a discharge capacity of $102 \mathrm{mAh} \mathrm{g}^{-1}$. Even at the relative high current density of 1500 and $3000 \mathrm{~mA} \mathrm{~g}^{-1}$, the $\mathrm{LiNi}_{0.05} \mathrm{Mn}_{1.95} \mathrm{O}_{4}$ electrode still deliver initial discharge capacities of 95.0 and $88.7 \mathrm{mAh} \mathrm{g}^{-1}$, respectively. Ni ion substitution can reduce capacity fading of spinel $\mathrm{LiMn}_{2} \mathrm{O}_{4}$ during cycling in $0.5 \mathrm{~mol} \mathrm{~L}^{-1} \mathrm{Li}_{2} \mathrm{SO}_{4}$ aqueous solution. After 800 cycles, the discharge capacity of the $\mathrm{LiNi}_{0.05} \mathrm{Mn}_{1.95} \mathrm{O}_{4}$ electrode fades from 94.3 to $74.9 \mathrm{mAh} \mathrm{g}{ }^{-1}$ with the loss of 20.6 $\%$ of its initial capacity at a current density of $1500 \mathrm{~mA} \mathrm{~g}^{-1}$. Although the reversible capacity of 
the $\mathrm{LiNi}_{0.1} \mathrm{Mn}_{1.9} \mathrm{O}_{4}$ electrode is the smallest it fades only from 71.0 to $64.7 \mathrm{mAh} \mathrm{g}^{-1}$, about $91.1 \%$ capacity retention.

Acknowledgments

The authors acknowledge financial support from MOST Programs (2010DFA61770), NSFC (21073046) and an Australian Research Council (ARC) Discovery Project (DP100103909). 
References:

[1] P. Simon, Y. Gogotsi, Nat. Mater. 7 (2008) 845.

[2] Y.P.Wu, X.B. Dai, J.Q. Ma, Y.J. Cheng, Lithium Ion Batteries: Practice and Applications, Chemical Industry Press, Beijing, 2004.

[3] J. M. Tarascon, M. Armand, Nature 414 (2001) 359.

[4] W. Tang, X.J. Wang, Y.Y. Hou, L.L. Li, H. Sun, Y.S. Zhu, Y. Bai, Y.P. Wu, K. Zhu, T. van Ree, J. Power Sources 198 (2012) 308.

[5] T. Kakuda, K. Uematsu, K. Toda , M. Sato, J. Power Sources 167 (2007) 499.

[6] K.S. Lee, S.T. Myung, K. Amine, H. Yashiro, Y.K. Sun, J. Mater. Chem. 19 ( 2009) 1995.

[7] F. Jiao, J.L. Bao, A.H. Hill, P.G. Bruce, Angew. Chem. Int. Ed. 47 ( 2008) 9711.

[8] D.K. Kim, P. Muralidharan, H.W. Lee, R. Ruffo, Y. Yang, C.K. Chan, H.L. Peng, R.A. Huggins, Y. Cui, Nano Lett. 8 (2008) 3948.

[9] K.M. Shaju, Peter G. Bruce, Chem. Mater. 20 (2008) 5557.

[10] A. Sakunthala, M. Reddy, S. Selvasekarapandian, B. Chowdari, P. Selvin, Electrochim Acta 55 (2010) 4441.

[11] Y.Y. Xia, Y.H. Zhou, M. Yoshio, J. Electrochem.Soc. 144 (1997) 2593.

[12] M.M. Thackeray, Y.S. Horn, A.J. Kahaian, K.D. Kepler, J.T. Vaughey, S.A. Hackney, Electrochem. Solid-State Lett. 1 (1998) 7.

[13] W. Li, W.R. McKinnon, J.R. Dahn, J. Electrochem. Soc. 141 (1994) 2310.

[14] W. Li, J.R. Dahn, D.S. Wainwright, Science 264 (1994) 1115.

[15] R. Ruffo, F.L. Mantia, C. Wessells, R.A. Huggins, Y. Cui, Solid State Ionics 192 (2011) 289.

[16] M.S. Zhao, X.P. Song, F. Wang, W.M. Dai, X.G. Lu, Electrochim. Acta 56 (2011) 5673. 
[17] F. Wang, Y. Liu, C.Y Liu, Electrochim. Acta 55 (2010) 2662.

[18] A. Yuan, L. Tian, W. Xu, Y. Wang, J. Power Sources 195 (2010) 5032.

[19] R. Ruffo, C. Wessells, R.A. Huggins, Y. Cui, Electrochem. Commun. 11 (2009) 247.

[20] W. Xu, A. Yuan, Y. Wang, J. Solid State Electrochem 16 (2012) 429.

[21] J.Y. Luo, W.J. Cui, P. He, Y.Y. Xia, Nat. Chem. 2 (2010) 760.

[22] J. Y. Luo, Y.Y. Xia, J. Power Sources 186 (2009) 224.

[23] P. He, J.Y. Luo, J.X. He, Y.Y. Xia, J. Electrochem. Soc. 156 (2009) A209.

[24] Q.T. Qu, L.J.Fu, X.Y. Zhan, D. Samuelis, J. Maier, L.Li, S. Tian, Z.H. Li, Y.P. Wu, Energy. Environ. Sci. 4 (2011) 3985.

[25] W. Tang, S. Tian, L.L. Liu, L.Li, H.P. Zhang, Y.B. Yue, Y. Bai, Y.P. Wu, K. Zhu, Electrochem.Commun. 13 (2011) 205.

[26] W. Tang, L.L. Liu, S. Tian, L. Li, L.L. Li, Y.B. Yue, Y. Bai, Y.P. Wu, K. Zhu, R. Holze, Electrochem. Commun. 13 (2011) 1159.

[27] W. Tang, L.L. Liu, Y.S. Zhu, H. Sun, Y.P. Wu, K. Zhu, Energy Environ. Sci. 5 (2012) 6909.

[28] W. Tang, X.W. Gao, Y.S. Zhu, Y.B. Yue, Y. Shi, Y.P. Wu, K. Zhu, J. Mater. Chem. 22 (2012), DOI:10.1039/C2JM34563C

[29] Y.K. Sun, S.H. Jin, J. Mater. Chem. 8 (1998) 2399.

[30] Y.K. Sun, Y.S. Jeon, J. Mater. Chem. 9 (1999) 3147.

[31] C. Bellitto, E.M. Bauer, G. Righini, M.A. Green, W.R. Branford, A. Antonini, M. Pasquali, J. Phys. Chem. Solids 65 (2004) 29.

[32] S.S. Zhang, K. Xu, T.R. Jow, Electrochim. Acta 49 (2004) 1057.

[33] S.J. Bao, Y.Y. Liang, W.J. Zhou, B.L. He, H.L. Li, J. Power Sources 154 (2006) 239

[34] N. Santander, S.R. Das, S.B. Majumder, R.S. Katiyar, Surf. Coat. Technol. 60 (2004) 177. 
[35] S. Devaraj, N. Munichandraiah, J.Electrochem. Soc. 154 (2007) A80.

[36] Y.M. Choi, S.I. Pyun, Solid State Ionics 99 (1997) 173.

[37] Y.P. Wu, E. Rahm, R. Holze, Electrochim. Acta 47 (2002) 3491. 


\section{Captions of Figures and Tables}

Fig. 1 XRD patterns of $\mathrm{LiNi}_{x} \mathrm{Mn}_{2-x} \mathrm{O}_{4}(\mathrm{x}=0,0.05,0.10)$ samples.

Fig. 2 SEM micrographs of $\mathrm{LiNi}_{x} \mathrm{Mn}_{2-x} \mathrm{O}_{4}$ samples: (a) $\mathrm{x}=0$, (b) $\mathrm{x}=0.05$, (c) $\mathrm{x}=0.1$.

Fig. 3 The cyclic voltammograms of the $\mathrm{LiNi}_{x} \mathrm{Mn}_{2-x} \mathrm{O}_{4}$ samples for (a) $\mathrm{x}=0$, (b) $\mathrm{x}=0.05$ and (c) $\mathrm{x}=0.1$ at different scan rates, and (d) the Nyquist plots of the $\mathrm{LiNi}_{\mathrm{x}} \mathrm{Mn}_{2-\mathrm{x}} \mathrm{O}_{4}(\mathrm{x}=0,0.05$ and 0.1) electrodes.

Fig. 4 The first charge/discharge profiles of the $\mathrm{LiNi}_{\mathrm{x}} \mathrm{Mn}_{2-\mathrm{x}} \mathrm{O}_{4}(\mathrm{x}=0,0.05$ and 0.1$)$ samples at charge and discharge current densities of (a) 150, (b) 300, (c) 1500 and (d) $3000 \mathrm{~mA} \mathrm{~g}^{-1}$.

Fig. 5 Rate capabilities of the $\mathrm{LiNi}_{\mathrm{x}} \mathrm{Mn}_{2-\mathrm{x}} \mathrm{O}_{4}(\mathrm{x}=0,0.05$ and 0.1$)$ samples at charge-discharge current densities ranging from 300 to $5000 \mathrm{~mA} \mathrm{~g}^{-1}$.

Fig. 6 Cycling performance of the $\mathrm{LiNi}_{x} \mathrm{Mn}_{2-x} \mathrm{O}_{4}(\mathrm{x}=0,0.05$ and 0.1$)$ samples at a charge and discharge current density of (a) 300 and (b) $1500 \mathrm{~mA} \mathrm{~g}^{-1}$.

Tab. 1 Chemical composition and BET surface area of the prepared samples. 


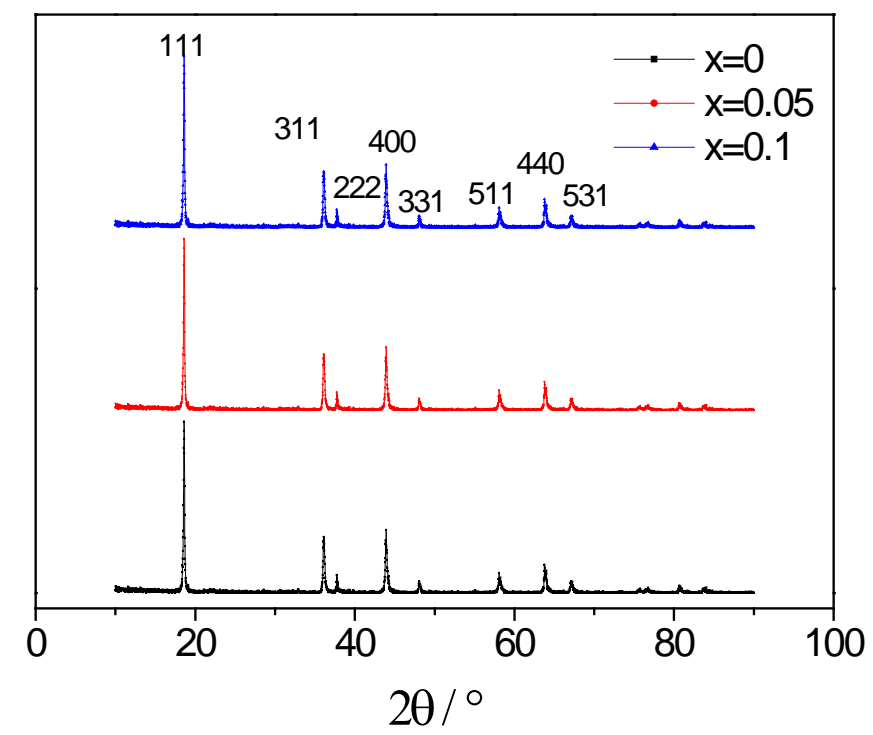

Fig. 1 

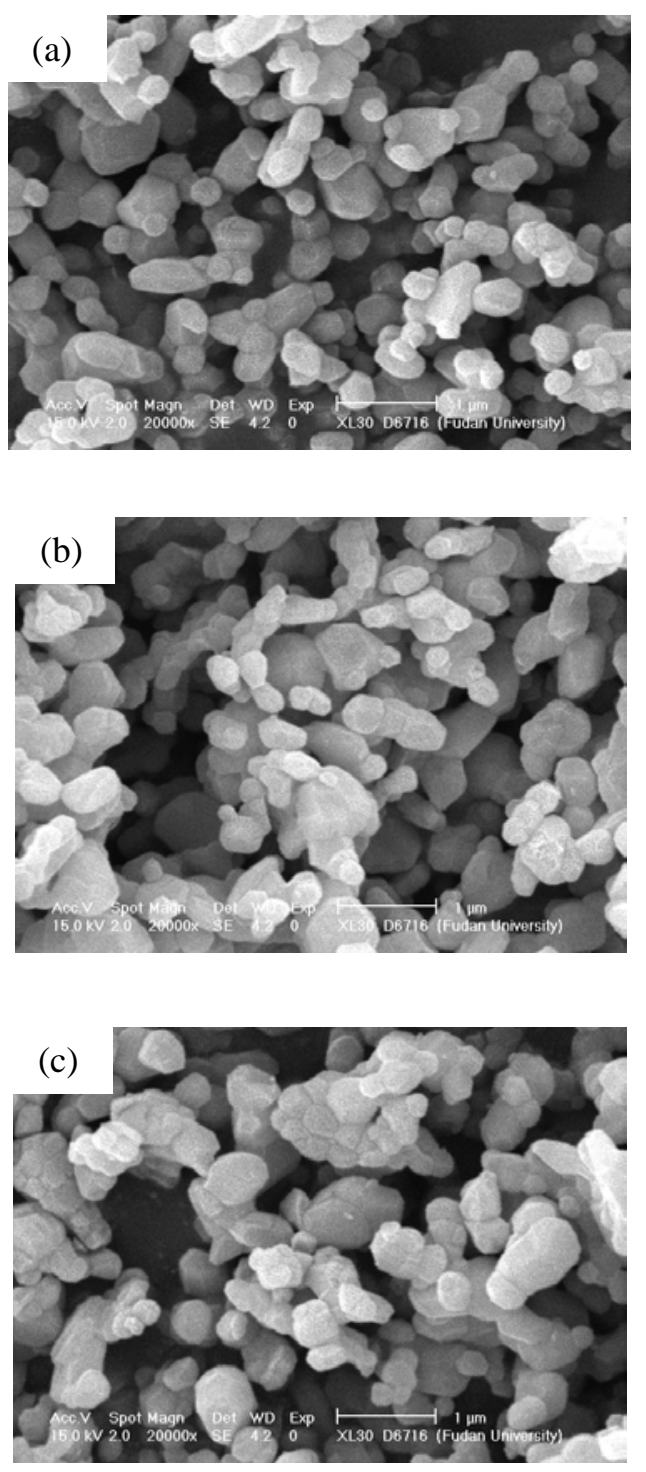

Fig. 2 

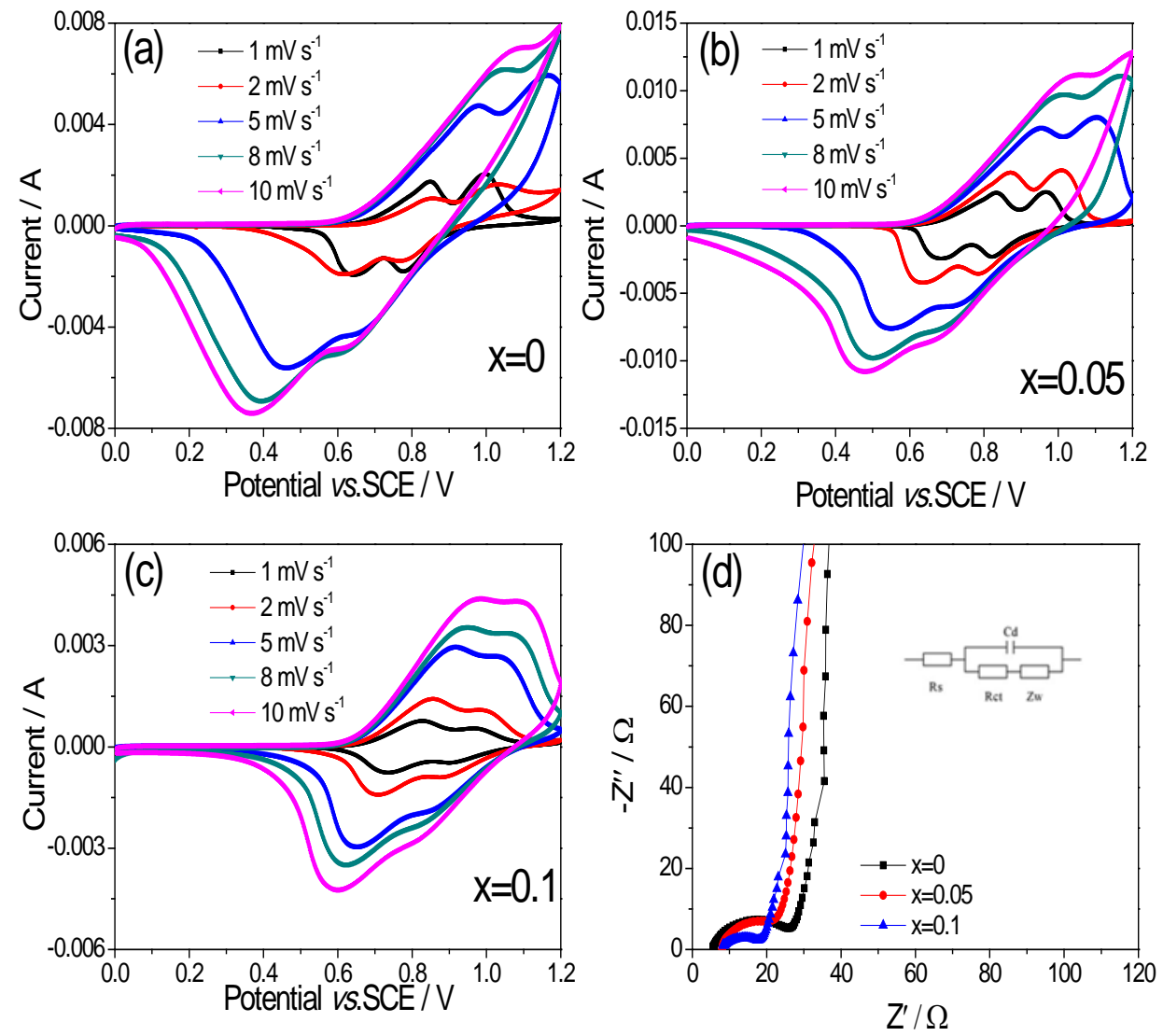

Fig. 3 

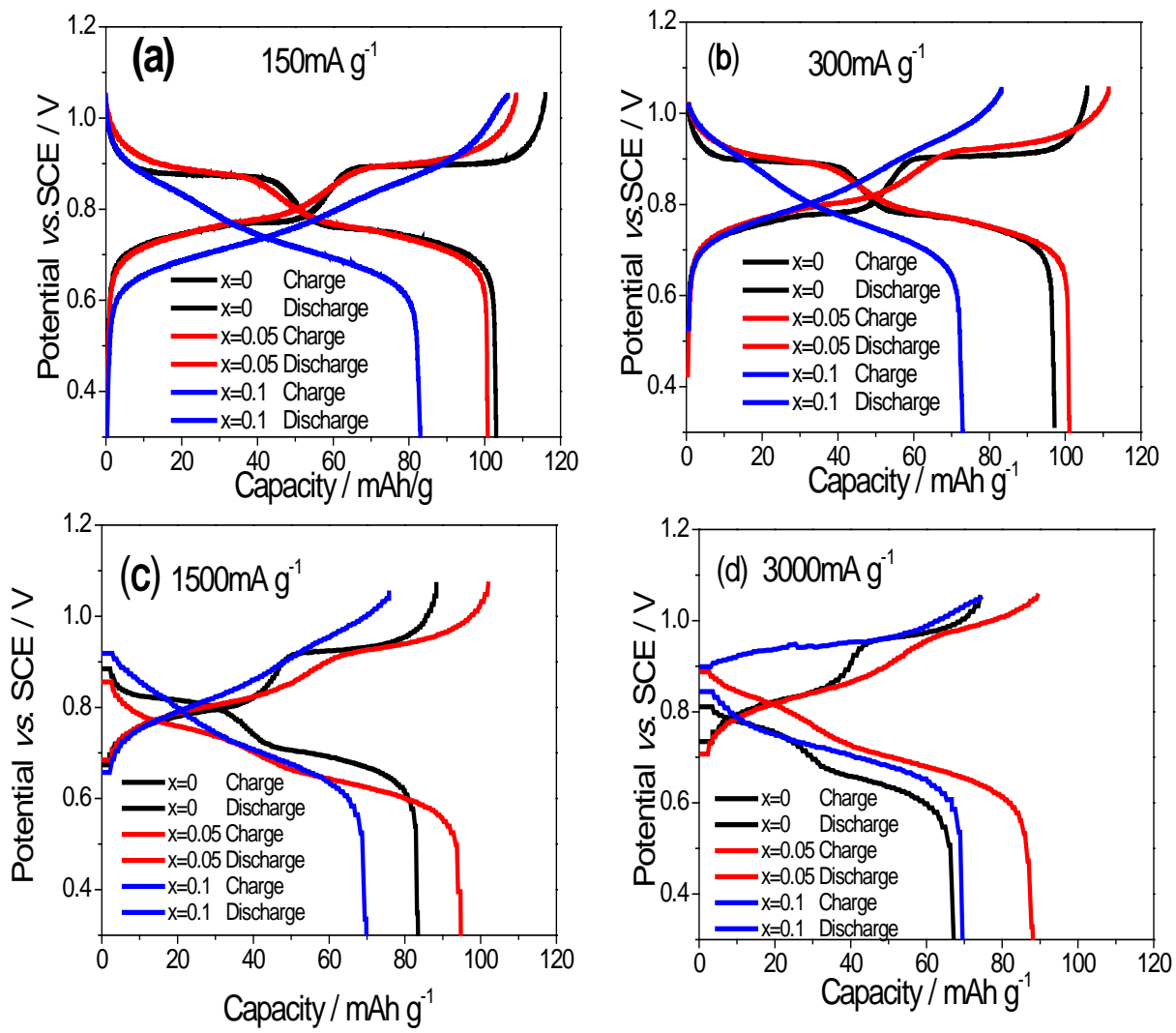

Fig. 4 


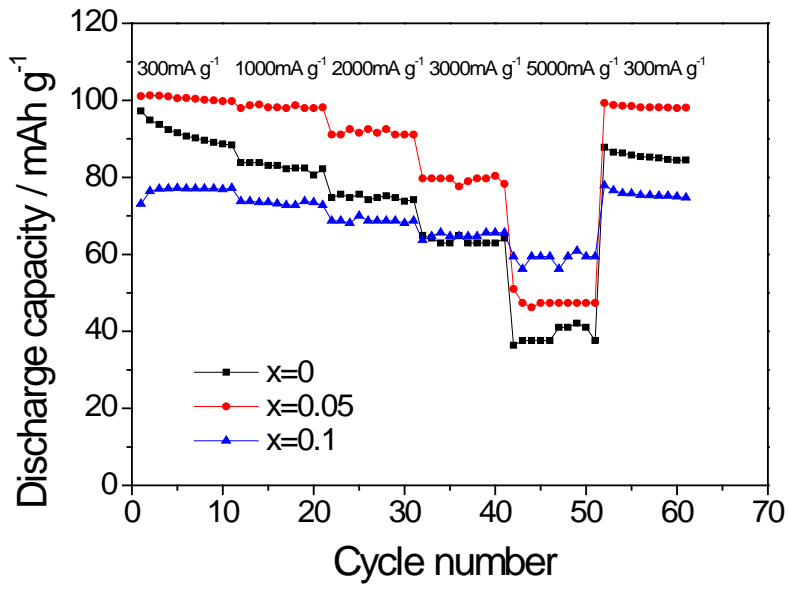

Fig. 5 

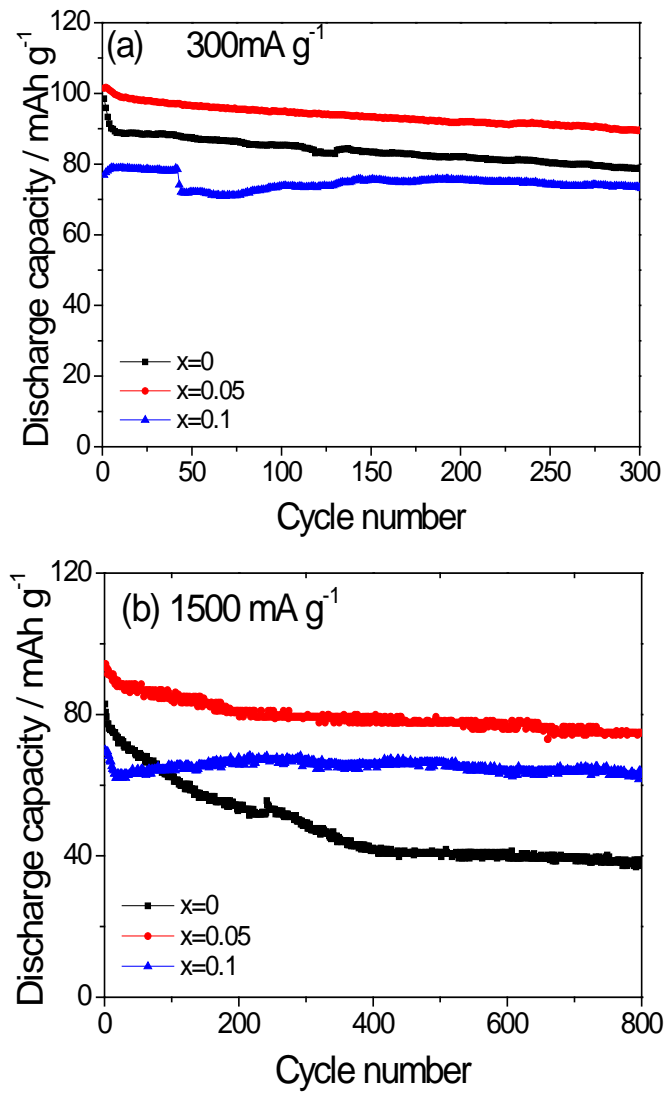

Fig. 6 
Tab. 1.

\begin{tabular}{llll}
\hline Samples: $\mathrm{LiNi}_{\mathrm{x}} \mathrm{Mn}_{2-\mathrm{x}} \mathrm{O}_{4}$ & $\mathrm{x}=0.00$ & $\mathrm{x}=0.05$ & $\mathrm{x}=0.10$ \\
\hline Mass fraction of Mn & $60.14 \%$ & $59.09 \%$ & $57.15 \%$ \\
Mass fraction of Ni & $0 \%$ & $1.72 \%$ & $3.37 \%$ \\
Molar ratio of Mn:Ni from ICP-AAS & $2.00: 0$ & $1.95: 0.053$ & $1.90: 0.105$ \\
& & & $1.90: 0.10$ \\
Theoretical molar ratio of Mn:Ni & $2.00: 0$ & $1.95: 0.05$ & 1.97 \\
Surface area / m ${ }^{2} \mathrm{~g}^{-1}$ & & & \\
\end{tabular}

